Vol. 10, pp. 1-17, ISSN: 2072-0394

\title{
Women's Rights In The Light Of Quran
}

\author{
Abida Parveen \\ Sheikh Zayed Islamic Center \\ University of Karachi
}

\begin{abstract}
Islam has given honour and rights to women. Before the advent of Islam, women were a suppressed section of the society. Islam evaluated the status of women which anyone can expect in today's modern society. Islam provides complete code of life, thus giving all social, economic, political and legal rights to women. A man and woman cannot be same physically so their rights can also not be the same due to their duties but they have equal rights in society. Prophet Muhammad (Peace be upon him) stressed that when some conflict between husband and wife becomes sharpened and there seems no solution, in this situation if wife no more wants to live with husband then she has the right to get divorce. In case husband do not want to give divorce, women has right to go to court for khula.
\end{abstract}

Key Words: Women's Right, Islam, Quran

$$
\begin{aligned}
& \text { ثلخيص }
\end{aligned}
$$

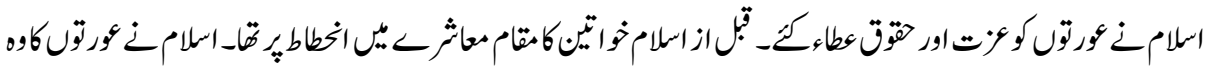

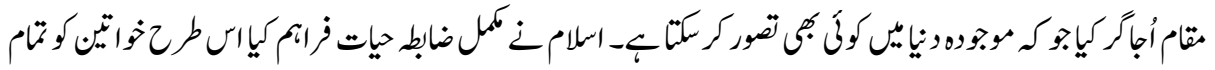

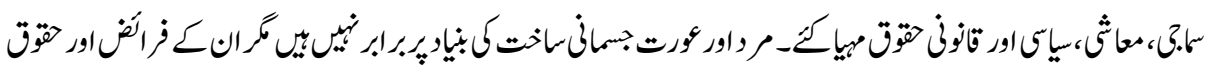

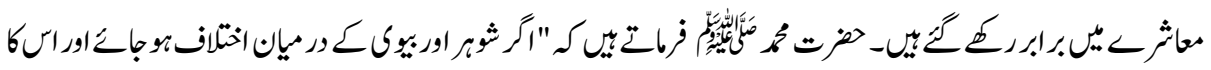

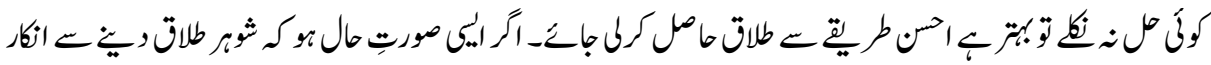

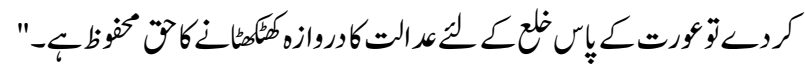

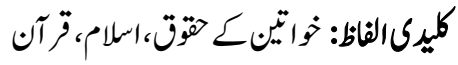

We are unaware of the importance and value Islam places upon women. People with insufficient knowledge of the Quran, try to protect their rights by working within their worldview, which follows the logic of unbelief. Social conditions around us make this reality very obvious. For example, many women continue to be exposed to ill treatment, violence, and unemployment, and need to be taken care of after their husbands have either divorced or abandoned them, or have died. 
Many verses of Quran protect women and their rights for the Quran eliminated the prevalent misguided stereotypes of woman and gave them a respectable position in society. Our Lord teaches us that superiority in His presence is based not on gender, but rather on one's fear and respect of Allah, faith, good character, devotion and dedication.

\section{The Holy Quran says:}

Whosoever doth right whether male or female and is a believer, him verily we shall quicken with good life and we shall pay $t$ hem a recompense in proportion to the best of what they used to do. (1)

Whose doth on ill-deed he will be repaid the like thereof while whoso doth right whether male or female and is a believer (all) such will enter the Garden, where they will be nourished without stint. (2)

Before the advent of Islam, the Women were treated in a cruel way. When if one of them recieveth tidings of the birth of a female, his face remaineth darkened and he is wroth in wardly. He hideth himself from the folk because of the evil of that whereof he hath had tidings (asking himself); shall he keep it in contempt or bury it beneath the dust verily evil is their judgment (3). And when the girl child that was buried alive is asked for what sin she was slain. (4)

\section{It is further said:}

"Slay not your children fearing a fall to poverty, We shall provide for them and for you. Lo! The slaying of them is great sin. (5)

Islam said for the inheritance of property rights for women in these words: "O ye who believe! It is not lawful for you forcibly to inherit the women (of your deceased kinsmen) noor (that ye should put constraint upon them that ye may take away a part of that which ye have given them unless they be guilty of flagrant lawdness. But consort with them in kindness for if ye hate them it may happen that ye hate a thing where in Allah hath placed much good. (6)

\section{In other place the Quran mentions:}

Forbidden unto you are your mother and your daughters and your sister and your father's sister and your mother's sister and your brother's daughter and your sister's daughter and your foster mother and foster sister and your mothers, mothers in law and your step-daughters who are under your protection (born) of your women unto whom ye have 
gone-in-but if ye have not gone in unto them it is no sin for you (to marry their daughters) and the wives of your sons who (spring) from your own loins, and (it is forbidden unto you) that ye should have two sisters together except what hath already happened (of that nature) in the past. Lo! Allah is ever Forgiving, Merciful. And all married women care forbidden unto you save those captives) whom your right hands possess. It is a decree of Allah for you. Lawful unto you are all beyond those mentioned. So that ye seek them with your wealth in honest wedlock, not debauchery. And those of whom y eseek content (by marrying them) given unto them their portions as a duty. And natural agreement after the duty (hath been tho) Lo! Allah is Ever-Knower and Wise (7)

\section{The Quran stresses the right of wife after marriage:}

And marry not those women whom your fathers married except what hath already happened (of that nature) in the past. Lo! It was ever lawdness and abominationand evil way. Forbidden unto you are your mother and your daughters, and your sisters, and your, your father's sisters and your mother's sisters and your brother's daughter and your sister's daughters and your foster-mother and your foster sister and your mothers-in-law and your step-daughters who are under your protection (born) of your women unto whom ye have gone-in but if ye have not gone-in unto them, then it is no sin for you (to marry their daughters) and the wives of your son who (spring) from your own loins. And (it is forbidden unto you) that ye should have two sisters together, except what hath already happened (of that nature) in the past. Lo! Allah is ever-forgiving, Merciful. (8)

Quran gives importance to women and give equal status with men and says: By the night enshrouding, and the day resplendent.And Him who hath created male and female. Lo! Your effort is dispersed (toward divers ends). (9)

\section{Quran States}

Therefore, we said! O Adam! This is an enemy unto thee and unto thy wife, so let him not drive you both out of the Garden so that thou come toil. It is (vouehsa fod) thoug unto thee that thou hungerest not therein nor art naked. And that thou thirstest not therein not are exposed to sun's head.But the Devil whispered to him saying: O Adam! Shall I saw thee the tree of immortality and power that wasteth not way? Then they twain ate thereof, so that their shame 
became apparent unto them, and they began to hide by heaping on themselves some of the leaves of the Garden. And Adam disobeyed his Lord, so want astray. Then his Lord chose him and relented, toward him and guided him. He said: "Go down hance both of you one of you a foe unto the other. But if there come unto you from $\mathrm{Me}$ a guidance then whose alloweth My guidance, he will not go astray not come to grief. (10)

And covet not the thing in which Allah hath made some of you excel others unto men a fortune form that which they have earned and unto women a fortune form that which they have earned. (Envy not one another). Lo! Allah is ever-Knower of all things". (11)

Another place the Quran stresses:O ye who believe! Let not a folk deride a folk who may be better than they (are) not let women (deride) women who may be better than they are neither defame one another, nor insult one another by nick names. Bad is the name of lewdness after faith. And whoso turneth not in repentance such are evil-doers (12)

Allay says:And it becometh not a believing man or a believing woman, when Allah and His messengers have decided and affair (for them) that they should (after that) claim any say in their affair; and whoso is rebellious to Allah and His messengers he verily goeth astray in errormanifest. (13)

\section{Another place, the Quran Stresses:}

These it was who disbelieved and debarred you from the inviolable place of worship and debarred the offering from reaching its goal and if it had not been for believing men and believing women whom ye know not lest ye should tread them under foot and thus incur guilt for them unknowingly; that Allah might bring into His mercy whom $\mathrm{He}$ will if (the believers and the disbelievers) had been clearly separated, we verily punished those of them who disbelieved with painful punishment. (14)

In another verse, it is said:So know (O Muhammad) that there is no God save Allah and ask forgiveness for thy sin and for believing men and believing women. Allah knoweth (both) your Place of turmoil and your place of rest. (15) 
God shows us guidance:Lo! They who spread the slander are a gang among you. Deem it not a bad thing for you, nay it is good for you unto every man of them (will be paid) that which he hath earned of the sin, and as for him among them who had the greater share therein his will be an awful doom. Why did not the believers men and women when ye heard it think good of their own folk and say it is a manifest untruth. (16)

\section{Quran says:}

Lo! Those who give alms both men and women and lend unto Allah a goodly loan it will be doubled for them and theirs will be a rich reward. (17)

That he may bring the believing men and believing women into Garden underneath which rivers flow where in they will abide and may remit from them their evil deeds, that in the sight of Allah is the supreme triumph. (18)

\section{Quran Stresses:}

On the day when thou (Muhammad) will see the believers, men and women, their light shining forth before them and on their right hands (and wilt hear it said unto them) Glad news for you this day. Gardens underneath which rivers flow wherein. Ye are immortal. That is the supreme triumph. (19)

"The hypocrites both men and women proceed one from another. They enjoin the wrong and they forbid the right and they withhold their hands (from spending for the cause of Allah). They forget Allah, so $\mathrm{He}$ hath forgotten them. Lo! The hypocrites they are the transgressors.

Allah promiseth the hypocrites both men and women and the disbelievers fire of hell for their abodes. It will suffice them Allah curseth them and there is the lasting torment. (20)

So Allah punisheth hypocritical men and hypocritical women and idolatrous men and idolatrous women. But Allah pardoneth believing men and believing women and Allah is Forgiving, Merciful." (21) 
On the day when the hypocritical men and the hypocritical women will say unto those who believe. Look on us that we may borrow from your light. It will be said. Go back and seek for light."

Then there will separate them a wall wherein is a gate the inner side whereof containth mercy while the outer side thereof is toward the doom. (22)

Islam has given the right to women to marry a man according to her choice: "Allah citeth an example for those who disbeliever the wife of Noah and the wife of Lot who were under two of the righteous slaves yet betrayed them. So that they (the husbands) availed them naught against Allah and it was said (unto them). Enter the Fire along with those who enter and Allah eiteth an example for those who believe the wife of Pharaoh when she said My Lord! Build for me a home with thee in the Garden and deliver me from Pharaoh and his work and deliver me from evil-doing folk. And Mary, daughter of Imran whose body was chaste therefore we breathed therein something of our spirit. And she put faith in the words of her Lord and His scriptures and was of the obedient". (23)

Woman is a source of satisfaction in a family. She makes a house atmosphere comfortable.

And of His signs in this we created for you help mates from yourselves that ye might find rest in them and He ordained between you love and merry. Lo! herein indeed are portents for folk who reflect. (24)

Quran has provided certain spiritual responsibilities to a man. Quran says:"Men are incharge of women because Allah hath made the one of them to excel the other and because they spend of their property (for the support of women). So good women are the obedient guarding in secret that which Allah hath guarded. As for those from whom ye fear rebellion admonish them and banish them to beds apart and scourge them. Then if they obey you seek not a way against them. Lo! Allah is ever High-Exalted Great. (25)

And they (women) have right similar to those (of men) over them in kindness, and men are a degree above them Allah is Mighty, Wise.”(26)

(Liken they then to Allah) that which is bred up in outward show and is dispute cannot make it self-plain. (27) 
For divorce, Quran says: "Divorce must be pronounced twice and then (a woman) must be retained in honour or released in kindness. And it is not lawful for you that ye take from women ought of that which ye have given them except (in the case) when both fear that they may not be able to keep within the limits (imposed by) ALLAH and if ye fear that they may not be able to keep the limits of Allah in that case it is no sin for either of them if the women ransom herself these are the limits (imposed by) Allah transgress them not. For whose transgresseth Allah's limit such are wrong-doers." (28)

\section{In other Place, it is Mentioned:}

"O Prophet! When ye (men) put away women put them away for their (legal) period and reckon the period and keep your duty to Allah your Lord. Expel them not from their houses nor let them go forth unless they commit open immorality, sucrose the limits (imposed by) Allah and whose transgresseth Allah's soul. Thou knowest not it may be that Allah will afterward bring some new thing to pass. Then when they have reached their term take them back in kindness or part from them in kindness and call withess two just men among you and keep your testimony upright for Allah whose believeth in Allah and the last day is exhorted to act thus. And whosoever keepeth his duty to Allah. Allah will appoint away out for him and will provide for him from aquarter whence he hath no expectation. And whoever putteth his trust in Allah, $\mathrm{He}$ will suffice him. Lo! Allah bringeth His command to pass Allah hath set a measure for all things. (29)

\section{Islam gives Right to Women after Divorce:}

"And when ye have divorced women and they reach their man term place not difficulties in the way of their marrying their husbands if it is agreed between them in kindness. This is an admonition for him among you who believeth in Allah and the Last Day. That is more virtuous for you and cleaner. Allah knoweth ye know not."(30)

\section{Quran gives the Responsibility to Husband if:}

"Mothers shall suckle their children for two whole years; (that is) for those who wish to complete the suckling. The duty of feeding and clothing nursing mother in a seemly manner is upon the father of the child. No one should be charged beyond this capacity. A mother should not be made to suffer because of her child nor should he whom the child is born (be made 
to suffer) because of his child. And on the (father's) heir is incumbent the like of that (which was incumbent on the father."(31)

"Lo! In the creation of the heaven and the earth and in the difference of night and day are token (of his sovereignty) for men of understanding. Such as remember Allah standing, sitting and reclining and consider the creation of the heavens and the earth (and say) our Lord! Thou createdst not this in vain. Glory be to three! Preserve us from Doom of Fire! Our Lord whom thou causest to enter the Fire him indeed thou hast confounded for evil-doers there will be no helpers."

"Our Lord Lo! We have heard a crier calling unto Faith: Believe ye in your Lord. So we believed our Lord therefore, forgive us our sins and remit our evil deeds and make us die the dearth of the righteous. Our lord! And give us that which Thou hast promised to us by Thy messengers. Confound us not upon the Day of Resurrection. Lo! Thou breakest not the trust. And their Lord hath heard them (and He saith). Lo! I suffered not the work of and worker male or female. (32)

\section{Islam has Given the Right to Marriage Again After the "Iddat"}

Quran says:"Such of you as die and leave behind them wives they (the wives) shall wait keeping themselves apart four months and ten days. And when they reach the term (prescribed for them) then there is no sin for you in aught that they may do with themselves in decency. Allah is informed of what ye do." (33)

\section{Islam has Given Equal Rights to Wife and Husband.}

"As for those who accuse their wives but have no witneses except themselves let the testimony of one of them be four testimonies (swearing) by Allah that he is of those who speak the truth. And yet a fifth invoking the curse of Allah on him if he is of those who lie. And it shall avert the punishment from her if she bear witness before Allah four times that the thing he saith is indeed false. And a fifth (time) that he ."

Wrath of Allah be upon her if he speaketh truth. (34)

\section{God has Given Inheritance Right to Women}

Unto the men (of a family) belongeth a share of that which parents and near kindred leave and unto the womrn a share of that which parents and near kindred leave whether it be little or much a legal share. (35) 


\section{In Inheritance, Quran Provides the Right to Girls, Mother and Father}

Allah chargeth you concerning (the provisions) for your children to the male the equivalent of the portion of two females and if there be women more than two then theirs is two thirds of the inheritance and if there be one (only) then the half. And to his parents a sixth of the inheritance if he have a son; and if he have no son and his parents are his heirs then to his mother appertaineth the third and if he have appertainth the sixth after any legacy he may have bequeathed or debt (hath been paid) your parents or your children. Ye know not which of them is nearer unto you in usefulness. It is an injunction from Allah. Lo! Allah is Knower-Wise. (36)

\section{Quran Distributes the Share of Wife and Husband in this Way}

And unto you belongeth a half of that which your wives leaves, if they have no child, but if they have a child than unto you the fourth of that which they leave after any legacy they may have be queathed or debt (they may have contracted them hath been paid). (37)

\section{The Status of Women in Providing Witness to any Situation, the Quran Says}

O ye who believe! Whe ye contract a debt for a fixed term, record it in writing. Let a scribe record it in writing between you in (terms of) equity. No scribe should refuse to write as Allah hath taught him, so let him write, and let him who incurreth the debt dictate and let him observe his duty to Allah, his Lord and diminish naught thereof. But if he who oweth the debt is of low understanding or weak or unable himself to dictate, then let the guardian of his interests dictate in (term of) equity. And call to witness from among your men two witnesses. And if two men be not (at hand) then a man and two woman of such as ye approve as witnesses so that if the one erreth (through forgetfulness) the other will remember. And the witnesses must not refuse when they are summoned. (38)

\section{Islam Rose the Honour of Women Saying}

And those who accuse honourable women but bring not four witnesses scourge them (with) eighty strips and never (afterward) accept their testimony. They indeed are evil-doers, save those who afterward repent and make amends (for such) to Allah is Forgiving, Merciful. (39) 
Before the Advent of Islam, the Different Situations were Faced by the Women during the Period of Prophet Ibrahim (PBUH), Quran Says

Our Lord Lo! I have settled some of my posterity in an uncultivable valley near unto thy Holy House. Our Lord! That they may establish proper worship, so inctine some hearts of men that they may yearn toward them and provide. Thou them with fruits in order that they may be thankful. (40)

\section{During Prophet Moosa (Peace be upon him), Quran Says}

And when he came unto the water of Maidan he found there a whole tribe of men, watering. And he found apart from them two women keeping back (their flocks) He said what aileth you? The two said: "We cannot give (our flocks) to drink till the shepherd returns from the water and our father is a very old man. So he watered (their flock) for them. Then he turned aside into the shade, and said. My Lord! I am needy of whatever good Thou sendest down for me. Then there came unto him one of the two women walking shyly.

She said: Lo! My father biddeth thee that he may reward thee with a payment of thtat thou didst water (the flock) for us. Then when he came unto him and told him the (whole) story, he said: Fear not! Thou hast escaped from the wrong doing folk. (41)

So when she came it was said (unto her) Is thy throne like this? She said: (It is) as though it were the very one. And (Solomon said) we were given the knowledge before her and we had surrendered (to Allah). And (all) that she was wont to worship instead of Allah hindered her for she came of disbelieving folk. It was said unto her enter the hall. And when she saw it, she deemed it a pool and barred her legs. (Solomon) said! Lo! It is a hall made smooth of glass. She said! My Lord! Lo! I have wronged myself and I surrender with Solomon unto Allah the Lord of the worlds. (42)

\section{During the days of Prophet Muhammad (Peace be upon him), if}

Allah hath heard the saying (Muhammad) concerning her husband, and complaineth unto Allah. And Allah heareth your colloquy. Lo! Allah is Hearer, Knower. (43) 


\section{Prophet Gave Guidance to Men Meeting Women}

Tell the believing men to lower their gaze and be modest. That is purer for them. Lo! Allah aware of what they do. (44)

\section{Islam Says Women should Hide All Parts of their Bodies Except Face and Hands}

And tell the believing women to lower their gaze and be modest and to display of their adornment only that which is apparent and to draw their evils over their bosoms and not to reveal their adornment save to their own husbands or fathers or husband's father or their sons or their husband's sons, or their son or their brothers, son or sister's sons, or their women or their slaves, or male attendants who know naught of women's nakedness. And let them not stamp their feet so as to reveal what they hid of their adornment, and turn unto Allah together $\mathrm{O}$ believers, in order that ye may succeed. (45)

Women had always been a victim of untold tyranny in Arab and other parts of the world in all ages of history. Allah established it is first state under the Khilafah of Adam with this collaboration of Eve which continued to groom and develop with the joint efforts of men and women of their times until a full fledged khilafah got established under the leadership of the Holy Prophet Muhammad (peace be upon him). Allah honoured women by assigning three times more respect and honour to mothers than to men as fathers in this world and in the Hereafter. The Holy Quran has given equal rights in the following matters.

The men are capable of integrating themselves by obeying the laws of Allah and so are women.

Allah uses names of both i.e Al-Momineen wal Mominaat. Great honours have been for women as the wives of Prophet Muhammad (Peace be upon him) are known as Mothers of the Believers. Women enjoy equal rights with men in relation (1) Rights of People (Huquq-ul-Ibaad and (2) Rights of Allah (Huqu-Ullah).

Islam has settled the place of women, her status and the role in the society forever. Islam believes in a dual-sex society accepting the principles of the equality of men and women. Allah said that he has created everything on Haq (Justice or Balance). Women had always been a victim of untold tyranny in different societies. Women were in the worst condition prior to Islam and are victim of all sorts of tyranny even in this so-called age of enlightenment. 
In spite of increased awareness of their rights and their demands and efforts for emancipation much of the world societies continues to victimize them in a way or the other.

Islam reveals to mankind the desired of the men and women by establishing the same ethical obligations and rewards for both sexes.

\section{The Quran says:}

"And whosoever does good works whether male or female, and he (or she) is a believer, such will enter Paradise and they will not be wronged the dint in a date stone. (46)

\section{The Quran stresses:}

"Whosoever does right, whether male or female, and is a believer, we shall assuredly give him to live a good life, and we shall pay them a recompense according to the best of what they do." (47)

Allah gives equal status and value to men and women. The Quran proclaims the right of every women to buy and sell, to contact and to earn, and to hold and manage her own money and property. It give women a share inheritance of the family (48). Warns against depriving her of that inheritance (49) and specifies that dowry (Mahr) of her marriage should belong to her alone and never be taken by her husband unless offered by the woman as for gift. Islam not only recommends, but even insists upon the equality of women and women as an essential characteristics of a Muslim Society. Islam teaches that women and men are all creatures of Allah, existing on level of equal worth and value.

The rights of women have been fully preserved by Islam since the very beginning, God says in Quran:

"Do not entrust (their) property God has given you to maintain (on first to those who are immature; but feed them and clothe them from it and speak to them with kindness". (50)

\section{In some other verse it is said:}

"To men alluted that they earn, to women whey they earn" God thus decrees that men and women are equal in all respects of work and manners of earning livelihood." (51)

Islam considers men and women are equal as far as the rights are concerned. If not only recognizes a human personality for both, but also considers them equal in all rights and human privileges, 
"They (women) are a vestment of you, and you (men) are a vestment for them" (52). Both husband and wife have almost similar rights and enjoy equal status. (53)

Quran ordains man to treat his wife with affection (Surah iv-iv, v.19). Indeed affection for wife has been rated as highest of virtues.

\section{Prophet Muhammad (PBU) stressed that}

"The best of you are the kindest of you to their wives. God creates man and woman from a single soul and there from did create his mate, that he might dwell with her (love). (54).

The creature of heavens and earth. He has made for you pairs from among yourselves (55).

The Quran forbade the custom of killing of females and considered if a crime like any other murder.

"And when the female (infant) buried alive, is questioned, for what crime she was killed? (56)

For from saving the girl's life so that she may suffer injustice and inequality, Islam requires kind and just treatment for her. The saying of Prophet Muhammad (PBUH) in this regard, "Whosever had a daughter and does not bury her alive, does not insult her and does not favour his son over her, God will enter him in paradise."

The Quran states "But consort with them in kindness, for if you hate them it may happen that you hate a thing wherein God has placed much good". (57).

Thus, Islam considers men and women equal as far as fundamental rights are concerned. Islam recognizes them equal in all rights and human privileges.

\section{Conclusions}

Allah has revealed the steps that women need to take to ensure their protection and respect within society and for them to find the love and dignity that they deserve. All of these measures benefit women and seek to prevent damage to their interests or any form of oppression and unnecessary stress. 


\section{Equality of Women}

The facts that men and women have different physical builds and that women are generally weaker than men are irrelevant and cannot be used to reduce women's value. For Muslims, these issues were settled by the Qur'an: Men and women are equal. Allah reveals the qualities that all Muslims, male or female, should have:

The men and women of the believers are friends of one another. They command what is right and forbid what is wrong, keep up prayer and give the alms (zakat), and obey Allah and His Messenger. They are the people on whom Allah will have mercy. Allah is Almighty, All-Wise. (58)

One's gender has no bearing on this, for Allah has given everyone an intellect capable of leading him or her to the right path, reaching the right decisions, and giving the right responses in return for belief and devotion. Therefore, intellect has nothing to do with gender; rather, it has everything to do with one's devotion, fear and respect of Allah. When revealing things about unbelievers, Allah also addresses them in the same manner. He reveals that unbelievers and hypocrites of both genders will be treated alike.

"Anyone, male or female, who does right actions and believes, will enter the Garden. They will not be wronged by so much as the tiniest speck" (59).

Every mother suffers for many months and displays great devotion in order to give birth. As Allah reveals, this is an agonizing process for her. After this period, she adopts a selfless devotion and begins to feed and nurture her child. Allah reminds people of this reality and points out that mothers are very special beings.

We have instructed man concerning his parents. Bearing him caused his mother great debility, and the period of his weaning was two years:

"Give thanks to Me and to your parents. I am your final destination." (60)

Lord has decreed that you should worship none but Him, and that you should show kindness to your parents. Whether one or both of them reach old age with you, do not say "Ugh!" to them out of irritation, and do not be harsh with them; rather, speak to them with gentleness and generosity. Take them under your wing, out of mercy, with due humility and say:

"0 Lord, show mercy to them as they did in looking after me when I was small." (61)

Old age means the loss of physical strength, dynamism, health, and energy. Such people become dependent on other people's care, protection, and help. Their mental faculties 
decrease, and they come face to face with memory loss and other problems. In addition, He advises people not to forget their parents' selfless devotion to them and to treat them equally well when they reach old age and become dependent.

We have instructed man to honor his parents. (62) We have instructed man to be good to his parents. (63) Married Women

Relationships based on worldly values can degenerate into baseness, as often happens in marriage. When people's love and respect is based on these values, they can lose these feelings quickly when circumstances change. This is almost inevitable when love, respect, and loyalty depend on one's beauty, wealth, health, job, or status, for when these temporary and superficial characteristics disappear, so will the other person's love. Someone who follows such criteria will find no reason to continue to love and honor his or her spouse when the basis for those values is lost.

Belief, fear and respect of Allah, and decency of character are what make love, respect, and loyalty endure. Someone who loves his or her spouse for their belief and character will, in married life, be respectful, loyal, and decent. Losing one's youth, health, or beauty will not affect the love and consideration among spouses for each other, and neither will losing one's wealth or social status. They will not cause trouble or discontent to the other person because of their firm belief and fear and respect of Allah, whatever the circumstances. Believers will always be gentle and compassionate, as well as fair and tolerant, for they will consider this to be a responsibility entrusted to them by Allah.

So close is the marital relationship that the Qur'an says of the spouses:

"They are clothing for you, and you for them" (64).

In this verse, Allah reminds people that each spouse has equal responsibilities. The word "clothing" stands for the responsibility of guarding and protecting one another and also suggests that men and women have complementary qualities.

\section{Another verse states the importance of love and compassion in marriage:}

"Among His Signs is that He created spouses for you of your own kind, so that you might find tranquillity in them. And He has placed affection and compassion between you. There are certainly Signs in that for people who reflect" (65).

Believers consider their spouses to be gifts that Allah has given into their care, and therefore value one another greatly. They show affection and compassion when their spouse makes a mistake or falls short in some way, and know that behaving according to the Qur'an will help them overcome all difficulties and solve their problems. As a result, marriage helps both spouses find contentment and peace. 
With the phrase "you have been intimate with one another" (66), Allah proclaims the closeness and intimacy of married life. The secret of this closeness, intimacy, and valuing of each other is their intention to create an everlasting togetherness that will extend into the Hereafter. True loyalty and love requires this attitude. Since their love is neither selfish nor temporary, but intended to be everlasting, they are completely loyal, close, honest, and intimate with one another.

\section{References}

1. Al Quran Surat Al Nahl: 97

2. Al Quran Surat Al Momin: 40

3. Al Quran Surat Al Nahl: 58-59

4. Al Quran Surat Al Takweer: 8-9

5. Al Quran Surat Al Bani Israel: 3

6. Al Quran Surat Al Nisa: 19

7. Al Quran Surat Al Nisa: 22-23

8. Al Quran Surat Al Nisa: 22-23

9. Al Quran Surat Al Lail: 1-4

10. Al Quran Surat Al Taha: 117-123

11. Al Quran Surat Al Nisa: 32

12. Al Quran Surat Al Hujrat: 11

13. Al Quran Surat Al Ahzaab: 36

14. Al Quran Surat Al Fath: 25

15. Al Quran Surat Al Muhammad: 19

16. Al Quran Surat Al Noor: 11-12

17. Al Quran Surat Al Hadeed: 18

18. Al Quran Surat Al Fath: 5

19. Al Quran Surat Al Hadeed: 12

20. Al Quran Surat Al Tauba: 67-68

21. Al Quran Surat Al Ahzaab: 73

22. Al Quran Surat Al Hadeed: 13

23. Al Quran Surat Al Tahreem: 10-12

24. Al Quran Surat Al Roum: 21

25. Al Quran Surat Al Nisa: 34

26. Al Quran Surat Al Baqarah: 228

27. Al Quran Surat Al Zukhruf: 18

28. Al Quran Surat Al Baqarah: 229

29. Al Quran Surat Al Talaq: 13

30. Al Quran Surat Al Baqarah: 232

31. Al Quran Surat Al Baqarah: 233

32. Al Quran Surat Al Imran: 193-195 
33. Al Quran Surat Al Baqarah: 234

34. Al Quran Surat Al Noor: 6-9

35. Al Quran Surat Al Nisa: 7

36. Al Quran Surat Al Nisa: 11

37. Al Quran Surat Al Nisa: 12

38. Al Quran Surat Al Baqarah: 282

39. Al Quran Surat Al Noor: 4-5

40. Al Quran Surat Al Abraham: 37

41. Al Quran Surat Al Qasas: 23-25

42. Al Quran Surat Al Naml: 42-44

43. Al Quran Surat Al Mujadalah: 1

44. Al Quran Surat Al Noor: 30

45. Al Quran Surat Al Noor: 31

46. Al Quran Surat Al Nisa: 124

47. Al Quran Surat Al Nahl: 97

48. Al Quran Surat Al Nisa: 7-11

49. Al Quran Surat Al Nisa: 19

50. Al Quran Surat Al Nisa: 5

51. Al Quran Surat Al Nisa: 32

52. Al Quran Surat Al Baqarah: 187

53. Al Quran Surat Al Baqarah: 228

54. Al Quran Surat Al Aaraf: 187

55. Al Quran Surat Al Shuraa: 11

56. Al Quran Surat Al Takweer: 8-9

57. Al Quran Surat Al Nisa: 19

58. Al Quran Surat Al Tauba: 71

59. Al Quran Surat Al Nisa: 124

60. Al Quran Surat Al Luqman: 14

61. Al Quran Surat Al Isra: 23-24

62. Al Quran Surat Al Ankabut: 8

63. Al Quran Surat Al Ahqaf: 15

64. Al Quran Surat Al Baqarah: 187

65. Al Quran Surat Al Roum: 21

66. Al Quran Surat Al Nisa: 21

Dr. Abida Parveen is Associate Professor in the Sheikh Zayed Islamic Center, University of Karachi. 